Pesq. Vet. Bras. 37(8):871-873, agosto 2017 DOI: $10.1590 / \mathrm{S} 0100-736 \mathrm{X} 2017000800015$

\title{
Modified Schirmer tear test and rebound tonometry in blue- fronted Amazon parrot (Amazona aestiva) ${ }^{1}$
}

\author{
Mário S.A. Falcão², Rafael V. Monteiro², Arianne P. Oriá ${ }^{3}$ and Paula D. Galera ${ }^{2 *}$
}

\begin{abstract}
Falcão M.S.A., Monteiro R.V., Oriá A.P. \& Galera P.D. 2017. Modified Schirmer tear test and rebound tonometry in blue-fronted Amazon parrot (Amazona aestiva). Pesquisa Veterinária Brasileira 37(8):871-873. Departamento de Cirurgia de Pequenos Animais, Faculdade de Agronomia e Medicina Veterinária, Universidade de Brasília, Campus Universitário Darcy Ribeiro, Avenida L4 Norte, Asa Norte, Brasília, DF 70910-900, Brazil. E-mail: dra.paulagalera@gmail.com

The aim of this study was to describe the modified Schirmer tear test (mSTT), intraocular pressure (IOP) by rebound tonometry and palpebral fissure length (PFL) in blue-fronted Amazon parrots (Amazona aestiva). Thirty-five healthy adult animals from a conservation breeding center in Brazil were used in this study. Modified Schirmer tear test, rebound tonometry and PFL measurements were performed in both eyes, with birds under physical restraint. Mean $\mathrm{mSTT}$ was $6.2 \pm 0.1 \mathrm{~mm} / \mathrm{min}$ and mean IOP was $6.4 \pm 0.1 \mathrm{mmHg}$, while PFL was $10.1 \pm 0.1 \mathrm{~mm}$. A moderate correlation was seen between mSTT and PFL for OD $(\rho=0.14)$ and OS $(\rho=0.20)$. The results provide ophthalmic tests reference values for $A$. aestiva.
\end{abstract}

INDEX TERMS: Schirmer tear test, tonometry, Amazon parrot, Amazona aestiva, birds, lacrimal production, intraocular pressure, palpebral fissure length, wild animals.

RESUMO.- [Teste lacrimal de Schirmer modificado e tonometria de rebote em papagaio-verdadeiro (Amazona aestiva).] 0 objetivo deste estudo foi descrever o teste lacrimal de Schirmer modificado (TLSm), a pressão intraocular (PIO) pela tonometria de rebote e o comprimento da fissura palpebral (FP) do papagaio-verdadeiro (Amazona aestiva). Foram avaliados 35 papagaios adultos e saudáveis, provenientes de um Criadouro Conservacionista do Brasil. Após avaliação clínica e laboratorial, as aves foram fisicamente contidas para aferição, em ambos os olhos, do TLSm, da PIO pela tonometria de rebote e do comprimento da FP utilizando-se um paquímetro digital. Valor médio do TLSm foi $6.2 \pm 0.1 \mathrm{~mm} / \mathrm{min}$ e da PIO foi $6.4 \pm 0.1 \mathrm{mmHg}$, enquanto a aferição da FP foi $10.1 \pm 0.1 \mathrm{~mm}$. Uma correlação moderada foi observada entre TLSm e a FP para olho direito (OD) $(\rho=0.14)$ e olho esquerdo (OE) $(\rho=0.20)$. Os resultados po-

\footnotetext{
${ }^{1}$ Received on June 16, 2016.

Accepted for publication on November 18, 2017.

${ }^{2}$ Departamento de Cirurgia de Pequenos Animais, Faculdade de Agronomia e Medicina Veterinária, Universidade de Brasília, Campus Universitário Darcy Ribeiro, Avenida L4 Norte, Asa Norte, Brasília, DF 70910900, Brazil. *Corresponding author paulaeye@unb.br

${ }^{3}$ Escola de Medicina Veterinária e Zootecnia, Universidade Federal da Bahia (UFBA), Avenida Adhemar de Barros 500, Ondina, Salvador, BA 40170-110, Brazil
}

dem servir como valores de referência para testes oftálmicos para A. aestiva.

TERMOS DE INDEXAÇÃO: Teste lacrimal de Schirmer modificado, tonometria de rebote, papagaio-verdadeiro, Amazona aestiva, aves, produção lacrimal, pressão intraocular, comprimento da fissura palpebral, animais silvestres.

\section{INTRODUCTION}

The blue-fronted Amazon parrot (Amazona aestiva) measures $35-37 \mathrm{~cm}$ in length and weighs approximately $400 \mathrm{~g}$, reaching sexual maturity of age at five years. Individuals of this species have a predominant green color, yellow head with blue forehead, and black feet and beak (Forshaw 2010). Because of their vocalization skills similar to speech and interaction with humans, it is bred as a pet (Godoy 2007). Birds are considered animals with great visual acuity, which are important factors for breeding, feeding and flight (Hart 2002, Reuter et al. 2011, Williams 2012, Rauscher et al. 2013). The ophthalmic reference values used for the mSTT and rebound tonometry in these animals lack inter- and intraspecies information.

Due to the lack of specific data for A. aestiva, we aimed establish normal parameters for modified Schirmer tear test (mSTT), intraocular pressure (IOP), and palpebral fissure length (PFL). Also, to verify any correlation among mSTT and PFL. 


\section{MATERIALS AND METHODS}

Ethics statements. The study was approved by the Ethics Committee for Animal Use of the University of Brasilia (44763/2014). In addition, it was conducted in accordance with the ARVO Statement for the Use of Animals in Ophthalmic and Vision Research.

Animals. Thirty-five blue-fronted Amazon parrots (70 eyes), adults of undetermined sex, from a conservation breeding center accredited by IBAMA (Brazilian Institute of the Environment and Renewable Natural Resources), in the Central-West region of Brazil, were used in this research. The animals were phenotypically similar, with an average weight of $400 \mathrm{~g}$ (300-420 g).

The birds were captured with the help of nets and kept under physical restraint. The evaluations were performed on different animals per week, between 08:30 and 16:30 h, with an average temperature of $28 \mathrm{C}\left(18-29^{\circ} \mathrm{C}\right)$, and relative humidity of $62 \%$ (source: Clima Tempo). The parrots underwent clinical and laboratory evaluation (hematology and serum chemistry), followed by ophthalmic examination. Animals with visually detectable ocular abnormalities or clinical changes were not included in the study. The animals were subjected to inspection of the ocular surface and anterior segment structures by slit-lamp biomicroscopy (Kowa-SL ${ }^{\circledR}$; Kowa, Tokyo, Japan).

Ophthalmic parameters. All ophthalmic parameters were determined by the same investigator, in both eyes. The lacrimal production was measured by modified STT (mSTT) (Schirmer Tear Test $^{\circledR}$, Ophthalmos Fórmulas, São Paulo, SP, Brazil) (Fig.1A), IOP was determined by rebound tonometry $\left(\right.$ TonoVET $^{\circledR}$, Jorgensen Labs, Loveland, CO) (Fig.1B), and PFL was measured with a digital caliper (150 mm capacity with precision/accuracy: $\pm 0.01 \mathrm{~mm}$ ) (Fig.1C).

Modified STT was carried out using standardized strips cut in half, reducing the width of the $5 \mathrm{~mm}$ strip to $2.5 \mathrm{~mm} .^{7}$ The modified strips were placed into the lower conjunctival sac and kept for 60 seconds. The wetted length was immediately recorded. Tonometry was performed with the bird held in a vertical position, avoiding excessive pressure to the cervical region, to prevent iatrogenic IOP changes. Tono Vet ${ }^{\circledR}$ measurements were obtained once in each bird with the P setting, and only readings with no error bar were accepted.

A digital caliper was used to measure the horizontal length of the eyelid from lateral to medial commissure (palpebral fissure length), and the lids were kept closed during measurement.

Statistical analysis. Statistical analysis was performed with commercially available software (GraphPad Prism ${ }^{\circledR}$ ). Paired t-

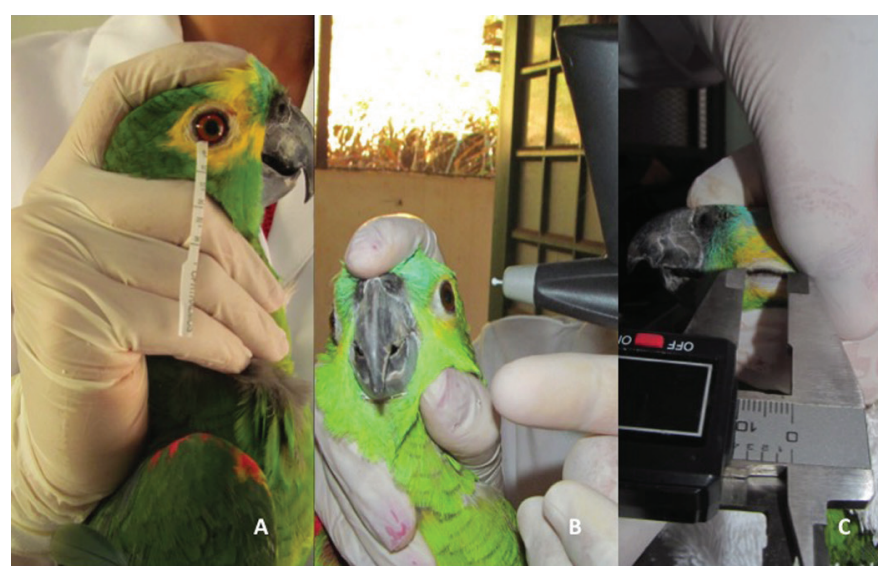

Fig.1. Ophthalmic evaluation of blue-fronted Amazon parrot, that was subjected (A) to mSTT, (B) rebound tonometry, and (C) measurement of palpebral fissure length (PFL) with digital caliper. -test was used for mSTT, IOP and PFL analyses. P-value $\leq 0.05$ was considered to be statistically significant. Correlation between PFL and mSTT was evaluated by Pearson correlation test $(\rho \geq 0.5)$.

\section{RESULTS}

Statistics results of mSTT, IOP and PFL are summarized in Table 1 . The Pearson correlation test showed a moderate correlation between mSTT and PFL for OS $(\rho=0.20)$ and OD $(\rho=0.14)$. No significant differences were observed comparing results obtained for $\mathrm{mSTT}$, IOP and PFL between right and left eyes $(\mathrm{P}>0.05)$.

Table 1. Modified Schirmer Tear test (mSTT), intraocular pressure (IOP) and palpebral fissure length (PFL) values of Amazona aestiva (*Mean $\pm \mathrm{SD})$

\begin{tabular}{ccc}
\hline $\mathrm{mSTT}(\mathrm{mm} / \mathrm{min})$ & IOP $(\mathrm{mmHg})$ & PFL $(\mathrm{mm})$ \\
\hline $6.4 \pm 3.8(\mathrm{OD})$ & $6.3 \pm 1.8(\mathrm{OD})$ & $10.1 \pm 1.0(\mathrm{OD})$ \\
$6.5 \pm 4.3(\mathrm{OS})$ & $6.1 \pm 2.0(\mathrm{OS})$ & $10.2 \pm 0.8(\mathrm{OS})$ \\
$6.2 \pm 0.1^{*}$ & $6.4 \pm 0.1^{*}$ & $10.1 \pm 0.1^{*}$
\end{tabular}

\section{DISCUSSION}

Prior to conducting this research, a pilot study was performed. It was not feasible to use the standard STT strip in the conjunctival sac of the lower eyelid, although Storey et al. (2009) have been successful using this method in assessing the parrot species $A$. ventralis. Even after inserting the strip into the conjunctival sac, the birds did not allow the strip to remain for the time required for tear measurement, probably due to the discomfort caused by the standard-sized test strip. It was found that the modified strip, as previously described (da Silva et al. 2013), was tolerated by the animals, without causing excessive stress. The STT has shown restrictions when used in small eyes (Willis \& Wilkie 1999, Müller et al. 2010, Beckwith-Cohen et al. 2015) which also was observed in the present study (Lange et al. 2012, Da Silva et al. 2013). According to Williams (2012), the use of a modified strip (cut in half with width of $2.5 \mathrm{~mm}$ ) is a viable option in species of birds with small eyes.

Meekins et al. (2015) utilized the mSTT strip in flamingo eyes, inserting it in the temporal canthus with the help of palpebral forceps, because they had difficulties placing the standard strip in the bottom of the conjunctival sac. The values found by these authors were higher $(12.3 \pm 4.5 \mathrm{~mm} /$ min) compared to parrots.

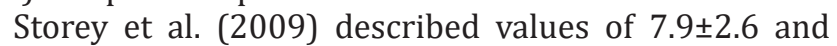
$5.1 \pm 3.3 \mathrm{~mm} / \mathrm{min}$ for STT-1 and STT-2, respectively, evaluating $A$. ventralis parrots, where the values obtained for STT-1 were above those measured for A. aestiva. Methodological modifications certainly affect the results obtained and should be considered in the interpretation of the findings, besides anatomic and physiologic characteristics of the species studied. One can also consider that using a narrower strip means a smaller contact surface between the filter paper and the ocular surface (Meekins et al. 2015), resulting in less moistening. It should be noted that the $A$. aestiva sample studied was phenotypically similar, and a substantial number of animals were assessed for this species, enhancing the reliability of the results.

Fluctuations in tear production are documented to be influenced by age, time of year, time of day and environmen- 
tal conditions (Wojick et al. 2013). In this study, tests were performed under the same conditions and time of year. It is also noteworthy that anatomic characteristics such as the position of the lacrimal gland and Harderian gland, which are closer to the nasolacrimal drainage system, can interfere with the moistening of the strip in these animals.

Given the difficulties described for the use of the STT strip (Willis \& Wilkie 1999, Müller et al. 2010, Beckwith-Cohen et al. 2015) or even mSTT strip (Williams 2012, Kern \& Colitz 2013, Somma et al. 2015, Meekins et al. 2015), some authors suggest the use of the phenol red test (Willis \& Wilkie 1999, Kern \& Colitz 2013, Beckwith-Cohen et al. 2015). Although this test is well tolerated by birds (Bliss et al. 2015), low reproducibility has been reported in large Psitacciformes (Holt et al. 2006), and better PRT reproducibility on $A$. ventralis (Storey et al. 2009).

Although applanation tonometry is considered an accurate and reliable method to measure IOP, it cannot be performed in eyes of animals with small corneal diameter (Rusanen et al. 2010, Barsotti et al. 2013) or it is not confortable, as it was observed with the Amazon parrot. Previous tonometry studies using the Goldmann tonometer have been reported for birds of prey (11-16. $\mathrm{mmHg}$ ) and parrots $(20-25 . \mathrm{mmHg})$. A study of 31 birds of prey using the rebound tonometer obtained an average of $9 \mathrm{mmHg}$, and in large birds, values close to $40 \mathrm{mmHg}$ (Bayon et al. 2007).

Rebound tonometry was introduced in the past decade in veterinary medicine, and has been used in poultry. According to Meekins et al. (2015), interference by the movement of the nictitating membrane in birds is less using rebound compared to applanation tonometry. Studies comparing rebound tonometry and a manometer showed that, in some birds, IOP was overestimated, while it was underestimated in others. However, even with these variations, the values obtained are considered useful for clinical application (Jeong et al. 2007, Reuter et al. 2010, Wojick et al. 2013). To minimize such oscillations, it is suggested that a single method be used for a particular species (Meekins et al. 2015).

In view of the regularity of the values obtained and the number of animals evaluated, under the conditions in which the study was conducted, the resulting data can be used for reference values for tear production and IOP in the blue-fronted Amazon parrot.

Acknowledgments.- The authors are grateful to Spazen Arte Vivenda, Distrito Federal, for allowing us to examine the parrots. Dr. A. Leyva helped with English translation and editing of the manuscript.

Conflict of interest statement.- The authors have no competing interests.

\section{REFERENCES}

Barsotti G., Briganti A., Spratte J.R., Ceccherelli R. \& Breghi G. 2013. Schirmer tear test type I readings and intraocular pressure values assessed by applanation tonometry (Tonopen ${ }^{\circledast} \mathrm{XL}$ ) in normal eyes of four European species of birds of prey. Vet. Ophthalmol. 16:365-369.

Bayon A., Almela R.M. \& Talavera J. 2007. Avian ophthalmology. Eur. J. Companion Anim. Pract. 17:253-265.

Beckwith-Cohen B., Horowitz I., Bdolah-Abram T, Lublin A. \& Ofri R. 2015.
Differences in ocular parameters between diurnal and nocturnal raptors. Vet. Ophthalmol. 18:98-105.

Bliss C.D., Aquino S. \& Woodhouse S. 2015. Ocular findings and reference values for selected ophthalmic diagnostic tests in the macaroni penguin (Eudyptes chrysolophus) and southern rockhopper penguin (Eudyptes chrysocome). Vet, Ophthalmol.18:86-93.

Da Silva E.G., Sandmeyer L.S., Gionfriddo J.R., Montiani-Ferreira F. \& Galera P.D. 2013. Tear production in canine neonates - evaluation using a modified Schirmer tear test. Vet. Ophthalmol. 16:175-179.

Forshaw J.M. 2010. Parrots of the World. Princeton University Press.

Godoy S.N. 2007. Psittaciformes (Arara, Papagaio, Periquito), p.222-224. In: Cubas Z.S., Silva J.C.R. \& Catão-Dias J.L. (Eds), Tratado de Animais Selvagens: medicina veterinária. Roca, São Paulo.

Hart N.S. 2002. Vision in the peafowl (Aves: Pavo cristatus). J. Exp. Biol. 205:3925-3935.

Holt E., Rosenthal K. \& Shofer F.S. 2006. The phenol red thread tear test in large Psittaciformes. Vet. Ophthalmol. 9:109-113.

Jeong M.B., Kim Y.J., Yi N., Park A.-E., Kim W.-T., Kim S.-E., Chae J.-M., Kim J.-T., Lee H. \& Seo K.-M. 2007. Comparison of the rebound tonometer (TonoVet ${ }^{\circledR}$ ) with the applanation tonometer (TonoPen $\mathrm{XL}^{\circledR}$ ) in normal Eurasian Eagle owls (Bubo bubo). Vet. Ophthalmol. 10:376-379.

Kern T.J. \& Colitz C.M.H. 2013. Exotic animal ophthalmology, p.1750-1819. In: Gelatt K.N., Gilger B.C. \& Kern T.J. (Eds), Veterinary Ophthalmology. 5th ed. Wiley-Blackwell, Philadelphia.

Lange R.R., Lima L. \& Montiani-Ferreira F. 2012. Measurement of tear production in black-tufted marmosets (Callithrix penicillata) using three different methods: modified Schirmer's I, phenol red thread and standardized endodontic absorbent paper points. Vet. Ophthalmol. 15:376-382.

Meekins J.M., Stuckey J.A., Carpenter J.W., Ambrust L., Higbie C. \& Rankin A.J. 2015. Ophthalmic diagnostic tests and ocular findings in a flock of captive American flamingos (Phoenicopterus ruber ruber). J. Avian Med. Surgery 29:95-105.

Müller K., Mauler D.A. \& Eule J.C. 2010. Reference values for selected ophthalmic diagnostic tests and clinical characteristics of chinchilla eyes (Chinchilla lanigera). Vet. Ophthalmol. 13:29-34.

Rauscher F.G., Azmanis P., Korber N., Koch C., Hubel J., Vetterlein W., Werner B., Thielebein J., Dawczynski J., Wiedrmann P., Reichenbach A., Francke M. \& Krautwald-Junghanns 2013. Optical coherence tomography as a diagnostic tool for retinal pathologies in avian ophthalmology. Invest. Opthalmol. Visual Sci. 54:8259-8269.

Reuter A., Muller K., Arndt G. \& Eule J.H. 2010. Accuracy and reproducibility of the TonoVet ${ }^{\circledR}$ rebound tonometer in birds of prey. Vet. Ophthalmol. 13:80-85.

Reuter A., Muller K., Arndt G. \& Eule J.C. 2011. Reference intervals for intraocular pressure measured by rebound tonometry in ten raptor species and factors affecting the intraocular pressure. J. Avian Med. Surgery 25:165-172.

Rusanen E., Florin M., Hassig M. \& Spiess B.M. 2010. Evaluation of a rebound tonometer Tonovet $^{\circledR}$ ) in clinically normal cat eyes. Vet. Ophthalmol. 13:31-36.

Somma A.T., Lima L., Lange R.R., Turner-Giannico A. \& Montiani-Ferreira F. 2015. The eye of the red-eared slider turtle: morphologic observations and reference values for selected ophthalmic diagnostic tests. Vet. Ophthalmol. 18:61-70.

Storey E.S., Carboni D.A., Kearney M.T. \& Tully Jr T.N. 2009. Use of phenol red thread tests to evaluate tear production in clinically normal amazon parrots and comparison with Schirmer tear test findings. J. Am. Vet. Med. Assoc. 235:1181-1187.

Williams D.L. 2012. Ophthalmology of Exotic Pets. Wiley-Blackwell, Iowa. Willis A.M. \& Wilkie D.A. 1999. Avian Ophthalmology. 1. Anatomy, Examination, and Diagnostic Techniques. J. Avian Med. Surgery 3:160-166.

Wojick K., Naples L.M. \& Knapp C.R. 2013. Ocular health assessment, tear production, and intraocular pressure in the Andros Island Iguana (Cyclura cychlura cychlura). J. Zoo Wildl. Med. 44:116-123. 